\title{
Konsensualne formy działań administracyjnoprawnych zastępujące lub uzupełniające decyzje administracyjne
}

1 - Konsensualność jako cecha aktów, czynności lub innych form konkretyzacji norm prawa administracyjnego stanowi wyjątek w sferze regulacji administracyjnoprawnej. Model stosowania norm prawa administracyjnego opiera się bowiem zasadniczo na władczej (imperatywnej) metodzie działania prawa. Konsensualne formy zachowań kompetencyjnych organów administracji publicznej są egzemplifikacjami zastosowania niewładczej (nieimperatywnej) metody konkretyzacji norm prawa administracyjnego ${ }^{1}$. Zbiór nieimperatywnych instrumentów lub form administracyjnoprawnych działań nie tworzy homogenicznej całości. Formy prawne działań zmierzających do zastosowania lub wykonania norm administracyjnoprawnych za pośrednictwem konstrukcji porozumienia (konsensusu) organów administracji publicznej lub podmiotów administrowanych mogą być uznane za istotny element powyższego zbioru. Formalna równorzędność stron aktu lub czynności konkretyzacji regulacji administracyjnoprawnej nie może być jednak utożsamiana $\mathrm{z}$ dwustronnością formy działania. Niezależnie bowiem od form dwustronnych (np. umów prywatnoprawnych lub administracyjnych) ${ }^{2}$ można także wyodrębnić konsensualne formy wielostronne (np. wielostronne

\footnotetext{
* Dr hab. Marcin Kamiński, Prof. UJ - Katedra Postępowania Administracyjnego Uniwersytetu Jagiellońskiegow Krakowie, e-mail: marcin.kaminski@uj.edu.pl

${ }^{1}$ Zob. np. M. Kamiński, Publicznoprawne obowiązki informacyjne w sferze norm publicznego prawa gospodarczego na tle ustawy o dostępie do informacji publicznej, w: Informacje gospodarcze. Studium prawne, red. A. Walaszek-Pyzioł, Warszawa 2018, s. 29 i n.

${ }_{2}^{2}$ Zob. np. J. Wyporska-Frankiewicz, Publicznoprawne formy działania administracji o charakterze dwustronnym, Warszawa 2010, s. 62 i n., 70 i n., 135 i n., 226 i n.
} 
ugody lub porozumienia administracyjne) ${ }^{3}$, których charakterystyczną cechą jest udział w procesie podejmowania czynności lub wydawania aktu co najmniej trzech podmiotów administrujących lub administrowanych. Akty lub czynności konsensualne, jako podgrupa form działania o charakterze niewładczym lub przewadze elementów niewładczych, zmierzają co do zasady do konkretyzacji norm administracyjnoprawnych za pośrednictwem złożenia zgodnych oświadczeń woli w przedmiocie ustalonej w trybie nieautorytatywnym treści powyższej konkretyzacji. Zakres aplikacji powyższych form w sprawach rozstrzyganych zasadniczo przez decyzje administracyjne lub ich wkomponowanie $\mathrm{w}$ proces jurysdykcyjnej konkretyzacji norm administracyjnoprawnych są nierzadko funkcją aktualnych celów prawodawczych lub dążeniem do wzrostu efektywności realizacji zadań publicznych. Wybór i sposób zastosowania konsensualnych form działania w sferze regulacji administracyjnoprawnej powinny być jednak zawsze efektem dojrzałej i szerokiej refleksji teoretycznej, która poprzedza proces ostatecznej prognozy skuteczności zastosowania określonych instrumentów prawnych do realizacji celów normodawczych.

2. W sferze regulacji administracyjnoprawnej szczególne znaczenie mają konsensualne formy działania stanowiące alternatywne formy prawne załatwiania spraw administracyjnych. Alternatywność tego rodzaju form może przejawiać się w możliwości wyboru formy prawnej załatwienia sprawy administracyjnej, pierwszeństwie użycia formy konsensualnej i subsydiarności decyzji administracyjnej albo możliwości zastąpienia (substytucji) już wydanej decyzji administracyjnej przez określony typ formy konsensualnej.

W pierwszym przypadku wybór formy działania może zostać pozostawiony podmiotom administrującym albo administrowanym. Typową formą prawną o charakterze konsensualnym, która może prowadzić do załatwienia sprawy administracyjnej i której wybór - co do zasady ${ }^{4}$ należy do podmiotów administrowanych, jest ugoda administracyjna ${ }^{5}$.

W polskim porządku prawnym forma ta jest aktem konsensualnym stron postępowania administracyjnego w sprawach o spornych interesach.

${ }^{3}$ Por. np. J. Boć, Działalność konsensualna (dwustronna i wielostronna), w: System prawa administracyjnego. Prawne formy działania administracji. Tom 5, red. R. Hauser, Z. Niewiadomski, A. Wróbel, Warszawa 2013, s. 234 i n.

${ }^{4}$ Niezależnie od sporności interesów stron postępowania (art. $13 \$ 1$ k.p.a.), charakteru danej kategorii sprawy administracyjnej (jej zdatności do załatwienia w drodze ugody administracyjnej) oraz dążenia do uproszczenia lub przyspieszenia postępowania, warunkiem zastosowania powyższej formy prawnej jest brak przepisu szczególnego, który wyłącza zawarcie ugody administracyjnej w określonej kategorii spraw administracyjnych (art. 114 k.p.a.). Zob. np. art. 118 ust. 2 ustawy z dnia 21 sierpnia 1997 r. o gospodarce nieruchomościami (Dz. U. z 2018 r. poz. 121 ze zm.): „W postępowaniu wywłaszczeniowym nie stosuje się przepisów o ugodzie administracyjnej”.

${ }^{5} \mathrm{~J}$. Wyporska-Frankiewicz, Publicznoprawne formy działania..., s. 70 i n. 
Nie jest to zatem forma prawna działania organów administracji publicznej. Warunkiem uzyskania przez ugodę skuteczności materialnoprawnej jest jej zatwierdzenie przez właściwy w sprawie organ administracji publicznej w drodze wydania odpowiedniego aktu administracyjnego (decyzji albo postanowienia). Ugoda administracyjna nie wywołuje zatem samodzielnie skutków prawnych właściwych dla decyzji administracyjnej. Dopiero władcze i ostateczne zatwierdzenie treści ugody w akcie administracyjnym skutkuje załatwieniem sprawy administracyjnej. Podstawy prawne instytucji ugody administracyjnej tworzą dwie grupy kategorialne.

Po pierwsze, można wyróżnić ogólną podstawę kompetencyjną wynikającą z przepisów ustawy z dnia 14 czerwca 1960 r. Kodeks postępowania administracyjnego (k.p.a.). Podstawa ta ma zastosowanie do wszystkich spraw administracyjnych zdatnych do załatwienia w drodze ugody administracyjnej, o ile przepisy szczególne nie stanowią inaczej.

Po drugie, można wyodrębnić szczególne podstawy kompetencyjne wynikające $z$ ustaw materialnego prawa administracyjnego. Podstawy tego typu konstruują najczęściej odrębne (szczególne) przesłanki zawarcia lub zatwierdzenia ugody. Ugody administracyjne tego rodzaju można określić mianem „ugód materialnoprawnych”. Przykładowo zgodnie z art. 235 ustawy z dnia 20 lipca 2017 r. - Prawo wodne ${ }^{6}$ właściciele gruntów mogą, w drodze pisemnej ugody, ustalić zmiany stanu wody na gruntach, jeżeli zmiany te nie wpłyną szkodliwie na inne nieruchomości lub na gospodarkę wodną. Ugoda nie może dotyczyć wprowadzania ścieków do wód lub do ziemi (ust. 1). Ugodę wykonuje się po jej zatwierdzeniu, w drodze decyzji, przez wójta, burmistrza lub prezydenta miasta (ust. 2). Ugoda niezatwierdzona nie podlega wykonaniu (ust. 4), natomiast zatwierdzona ugoda podlega wykonaniu w trybie określonym w przepisach ustawy z dnia 17 czerwca 1966 r. o postępowaniu egzekucyjnym w administracji ${ }^{7}$ (ust. 5).

Drugi typ alternatywności form konsensualnych względem decyzji administracyjnych polega na połączeniu zasady pierwszeństwa załatwienia sprawy $\mathrm{w}$ formie konsensualnej z subsydiarnym zastosowaniem formy decyzji administracyjnej w razie niedojścia alternatywnej formy do skutku.

Typowym przykładem powyższego wariantu zastosowania formy konsensualnej jest umowa o nabycie praw rzeczowych do nieruchomości objętej celem publicznym oraz zamiarem wywłaszczenia. Zasadą jest, że wywłaszczenie nieruchomości, polegające na pozbawieniu albo ograniczeniu prawa własności, prawa użytkowania wieczystego lub innego prawa rzeczowego na nieruchomości, następuje w drodze wydania decyzji administracyjnej

${ }^{6}$ Dz. U. z 2017 r. poz. 1566 ze zm.

7 Dz. U. z 2018 r. poz. 1314 ze zm. 
(art. 112 ust. 2 u.g.n. ${ }^{8}$ ). Jednakże wywłaszczenie jako ultymatywny środek ingerencji państwa w prawo własności nieruchomości ${ }^{9}$ może być dokonane jedynie wtedy, gdy cele publiczne nie mogą być zrealizowane w inny sposób niż przez pozbawienie albo ograniczenie praw do nieruchomości, a prawa te nie mogą być nabyte $\mathrm{w}$ drodze umowy (art. 112 ust. 3 u.g.n.) ${ }^{10}$. Umowa ta (tzw. umowa ekspropriacyjna) z formalnoprawnego punktu widzenia jest umową cywilnoprawną, jednakże jest ona zawierana na "przedpolu postępowania wywłaszczeniowego", co oznacza, że funkcjonuje ona jako administracyjnoprawny instrument realizacji celów publicznych ${ }^{11}$. $Z$ tego względu cecha konsensualności umowy ekspropriacyjnej jest wysoce ograniczona i ma wymiar przede wszystkim formalny.

Konsensualna forma umowna jako instrument wykonywania zadań i kompetencji administracyjnoprawnych występuje także w sprawach odszkodowań za nieruchomości wywłaszczone lub przejęte przez Skarb Państwa lub jednostki samorządu terytorialnego. Przykładowo zgodnie z art. 98 ust. 1 u.g.n. za działki gruntu wydzielone pod drogi publiczne lub pod poszerzenie istniejących dróg publicznych (gminnych, powiatowych, wojewódzkich, krajowych - z nieruchomości, której podział został dokonany na wniosek

${ }^{8}$ Ustawa z dnia 21 sierpnia 1997 r. o gospodarce nieruchomościami (Dz. U. z 2018 r. poz. 121 ze zm.), oznaczona skrótem „u.g.n.”.

${ }^{9}$ Zob. np. T. Woś, Wywłaszczanie nieruchomości i ich zwrot, Warszawa 2010, s. 159 i n.

${ }^{10}$ Zgodnie $\mathrm{z}$ art. 114 ust. 1 i 2 u.g.n. wszczęcie postępowania wywłaszczeniowego, z zastrzeżeniem art. 114 ust. 2 i ust. 3, należy poprzedzić rokowaniami o nabycie $\mathrm{w}$ drodze umowy praw określonych $\mathrm{w}$ art. 112 ust. 3, przeprowadzonymi między starostą, wykonującym zadanie z zakresu administracji rządowej, a właścicielem lub użytkownikiem wieczystym nieruchomości, a także osobą, której przysługuje do nieruchomości ograniczone prawo rzeczowe. W trakcie prowadzenia rokowań może być zaoferowana nieruchomość zamienna. W przypadku wywłaszczania nieruchomości na wniosek jednostki samorządu terytorialnego rokowania, o których mowa w ust. 1, przeprowadzają ich organy wykonawcze. Natomiast zgodnie z art. 115 ust. 2 u.g.n. wszczęcie postępowania wywłaszczeniowego następuje po bezskutecznym upływie dwumiesięcznego terminu do zawarcia umowy, o której mowa w art. 114 ust. 1, wyznaczonego na piśmie właścicielowi, użytkownikowi wieczystemu nieruchomości, a także osobie, której przysługuje ograniczone prawo rzeczowe na tej nieruchomości.

${ }^{11}$ Zob. uzasadnienie wyroku Trybunału Konstytucyjnego z dnia 12 grudnia 2017 r., sygn. akt SK 39/15, OTK ZU A/2017, poz. 86, Dz.U. z 2017 r. poz. 2375: „W tych okolicznościach pogląd o zbyciu nieruchomości w wyniku rokowań, o których mowa w art. 114 ust. 1 u.g.n., w warunkach swobody kontraktowania byłby - w ocenie Trybunału - nieuprawniony. Wręcz przeciwnie, $w$ istocie właściciel nieruchomości działa wówczas w warunkach „przymusu”. (...) Nie jest w pozycji równorzędnej $\mathrm{z}$ „kontrahentem”, lecz jest skonfrontowany z organem władzy publicznej gotowym użyć imperium w celu przejęcia nieruchomości. To nie on jest zresztą inicjatorem rokowań. Właściciel ma również świadomość, że jeśli w terminie 2 miesięcy nie zgodzi się na zawarcie umowy, organ wyda decyzję o wszczęciu postępowania administracyjnego, które doprowadzi - najprawdopodobniej - do wydania decyzji wywłaszczeniowej. (...) Umowa przewidziana w art. 114 ust. 1 u.g.n. jest co prawda instrumentem cywilistycznym, lecz w tym przypadku użyta została na potrzeby publicznoprawnej instytucji wywłaszczenia. Niezawarcie jej stanowi przesłankę wydania przez organ władzy publicznej jednostronnej decyzji o pozbawieniu lub ograniczeniu prawa własności”. 
właściciela lub użytkownika wieczystego) i przejęte na własność ${ }^{12}$ gminy, powiatu, województwa lub Skarbu Państwa z dniem, w którym decyzja zatwierdzająca podział stała się ostateczna albo orzeczenie o podziale prawomocne, byłemu właścicielowi lub użytkownikowi wieczystemu przysługuje odszkodowanie. Jeżeli wysokość odszkodowania ${ }^{13}$ nie zostanie uzgodniona między tymi podmiotami a właściwym organem (starostą), na wniosek byłego właściciela lub użytkownika wieczystego, odszkodowanie ustala się i wypłaca według zasad i trybu obowiązujących przy wywłaszczaniu nieruchomości (art. 98 ust. 3 u.g.n.). Z powyższej regulacji wynika, że „sprawa o odszkodowanie" za nieruchomości przejęte na cele drogowe może zostać załatwiona w trybie cywilnoprawnym lub administracyjnoprawnym. $\mathrm{Na}$ pierwszym etapie dochodzi do próby konsensualnego ustalenia wysokości i formy odszkodowania. Również w tym przypadku prywatnoprawna forma realizacji roszczenia odszkodowawczego byłego dysponenta praw rzeczowych nie znosi administracyjnoprawnej genezy tego roszczenia. Dopiero w sytuacji bezskutecznego zakończenia pierwszego etapu następuje przejście do etapu realizacji powyższego roszczenia na drodze administracyjnego postępowania jurysdykcyjnego. Ustalenie wysokości i formy realizacji odszkodowania (także w formie przyznania nieruchomości zamiennej) odbywa się w formie decyzji administracyjnej, która jest wydawana na zasadach obowiązujących przy ustalaniu odszkodowania za wywłaszczone nieruchomości, a więc zgodnie $z$ art. 128-135 u.g.n.

Pierwszeństwo załatwienia sprawy w formie konsensualnej może nie mieć charakteru obligatoryjnego. W takim wypadku cywilnoprawna umowa może zostać zawarta (eliminując konieczność wydania decyzji administracyjnej), jeżeli podmioty ustawowego obowiązku konkretyzowanego w drodze decyzji wyrażą wolę dobrowolnego ustalenia jego zakresu zanim dojdzie do wydania decyzji załatwiającej sprawę. Reprezentatywnym przykładem takiego rozwiązania są zawierane przez kierownika ośrodka pomocy społecznej umowy ustalające wysokość opłat za pobyt mieszkańca domu pomocy społecznej wnoszonych przez jego małżonka, zstępnych lub wstępnych (art. 103 ust. $2 \mathrm{w}$ zw. $\mathrm{z}$ art. 61 ust. 1 pkt 2 ustawy z dnia 12 marca 2004 r. o pomocy społecznej $\left.{ }^{14}\right)$. Jeżeli umowa tego rodzaju nie zostanie zawarta, a podmiotami zobowiązanymi do wnoszenia opłaty za pobyt w domu pomocy społecznej

${ }^{12} \mathrm{~W}$ przypadku nieruchomości obciążonych prawem użytkowania wieczystego prawo to wygasa z dniem, w którym decyzja zatwierdzająca podział stała się ostateczna albo orzeczenie o podziale prawomocne.

${ }_{13}$ Zgodnie z art. 98 ust. 3 zd. 2 w zw. z art. 131 u.g.n. w ramach odszkodowania byłemu właścicielowi lub użytkownikowi wieczystemu nieruchomości może być przyznana, za jego zgodą, odpowiednia nieruchomość zamienna.

${ }^{14}$ Dz. U. z 2017 r. poz. 1769 ze zm. Ustawa zwana dalej „u.p.s.”. 
są małżonek, zstępni lub wstępni mieszkańca domu pomocy społecznej (art. 61 ust. 1 u.p.s.), organ właściwej gminy jest zobowiązany do wydania decyzji ustalającej opłatę za pobyt w domu pomocy społecznej, podmioty zobowiązane do jej wnoszenia oraz wysokość ich zobowiązań (art. 59 w zw. $\mathrm{z}$ art. 61 u.p.s.).

Nietypowym wariantem relacji form konsensualnych do decyzji administracyjnych załatwiających określone typy spraw są sytuacje, w których umowa cywilnoprawna zastępuje już wydaną decyzję administracyjną, prowadząc do jej wygaśnięcia ${ }^{15}$. Wypieranie autorytatywnej i jurysdykcyjnej konkretyzacji prawa przez konsensualne formy umowne jest przejawem zauważalnej tendencji do stopniowania lub posiłkowego stosowania władztwa administracyjnego w sferze publicznego prawa gospodarczego. $\mathrm{O}$ ile specyfika relacji prawnych pomiędzy podmiotami danego sektora gospodarki lub rynku wewnętrznego może uzasadniać ograniczenie zastosowania władczych form działania organów administracji, o tyle zbyt swobodna lub pozbawiona uprzedniej kontroli właściwych organów praktyka wzajemnego zastępowania decyzji i umów regulujących tożsamą wiązkę uprawnień i obowiązków budzi poważne wątpliwości. Zakres obowiązywania ostatecznej decyzji administracyjnej nie powinien być bowiem kształtowany w dowolny sposób, pozostawiony autonomii woli stron skonkretyzowanego już stosunku administracyjnoprawnego. $\mathrm{W}$ istocie strony tego stosunku $\mathrm{w}$ dowolnym momencie i w dowolnie wyznaczonym zakresie mogą za pośrednictwem zawartej umowy doprowadzić do wygaśnięcia $\mathrm{z}$ mocy prawa ${ }^{16}$ wydanej już decyzji oraz do ustania skonkretyzowanego nią stosunku z zakresu prawa administracyjnego.

Egzemplifikacjami tego rodzaju rozwiązań są podstawy kompetencyjne przewidziane w ustawach z dnia 16 lipca 2004 r. Prawo telekomunikacyjne ${ }^{17}$ oraz z dnia 23 listopada 2012 r. Prawo pocztowe ${ }^{18}$.

Zgodnie $\mathrm{z}$ art. 28 ust. 1 w zw. $\mathrm{z}$ art. 28 ust. 2 i 2 b u.p.t. Prezes Urzędu Komunikacji Elektronicznej (UKE) podejmuje decyzję o dostępie telekomunikacyjnym w terminie 90 dni od dnia złożenia wniosku o wydanie decyzji w sprawie rozstrzygnięcia kwestii spornych lub określenia warunków współpracy

${ }^{15}$ Por. rozwiązanie przyjęte $\mathrm{w}$ art. $119 \$ 2$ k.p.a. Zgodnie z powyższym przepisem, w razie zawarcia ugody administracyjnej w toku postępowania odwoławczego, $\mathrm{z}$ dniem, w którym postanowienie o zatwierdzeniu ugody stało się ostateczne, decyzja organu pierwszej instancji traci moc (wygasa z mocy prawa), o czym zamieszcza się wzmiankę na powyższym postanowieniu.

${ }_{16}$ Zob. uwagi na ten temat - np. M. Kamiński, Materialnoprawne wygaśnięcie i proceduralne stwierdzenie wygaśnięcia mocy obowiązującej decyzji administracyjnej, w: Kodyfikacja postępowania administracyjnego. Na 50-lecie K.P.A., red. J. Niczyporuk, Lublin 2010, s. 255-264.

${ }_{17}$ Dz. U. z 2017 r. poz. 1907 ze zm. Ustawa zwana dalej „u.p.t.”.

${ }_{18}$ Dz. U. z 2017 r. poz. 1481 ze zm. Ustawa zwana dalej „u.p.p.”. 
dotyczących zawarcia umowy o dostępie telekomunikacyjnym w zakresie połączenia sieci lub zawarcia umowy o dostępie telekomunikacyjnym $\mathrm{z}$ operatorem obowiązanym do zapewnienia dostępu telekomunikacyjnego, którego obowiązek zapewnienia wynika z nałożonych na tego operatora obowiązków regulacyjnych. Decyzja o dostępie telekomunikacyjnym zastępuje umowę o dostępie telekomunikacyjnym w zakresie objętym decyzją (art. 28 ust. 4 u.p.t.). Jeżeli jednak zainteresowane strony stosunku prawnego dotyczącego dostępu telekomunikacyjnego, który został ukształtowany decyzją Prezesa UKE, zawrą następnie umowę o dostępie telekomunikacyjnym, wydana uprzednio decyzja wygasa z mocy prawa w części objętej umową (art. 28 ust. 5 u.p.t.). Analogiczne rozwiązania wynikają $z$ art. 131e u.p.t. Również w tym wypadku, w razie zawarcia przez zainteresowane strony umowy o dostępie do multipleksu, po wydaniu przez Prezesa UKE decyzji w sprawie rozstrzygnięcia kwestii spornych lub określenia warunków współpracy w zakresie dostępu do multipleksu, wydana uprzednio decyzja wygasa $\mathrm{z}$ mocy prawa w części objętej umową (art. 131e ust. 4 u.p.t.). Nieco odmienny kształt nadano regulacji dotyczącej zasad zastępowania decyzji o dostępie do elementów infrastruktury pocztowej umową dotyczącą tego dostępu. W art. 69 ust. 3 u.p.p. przewidziano, że w przypadku zawarcia umowy o tego rodzaju dostęp decyzja w sprawie dostępu „wygasa w zakresie objętym umową”. Należy przyjąć, że pomimo niezamieszczenia w powyższym przepisie wyrażenia „wygasa z mocy prawa”, utrata mocy obowiązującej przez decyzję o dostępie do elementów infrastruktury pocztowej następuje ipso iure.

3. Odrębne i wyjątkowe miejsce w sferze regulacji administracyjnoprawnej zajmują rozwiązania normatywne ustanawiające podstawy kompetencyjne do uzupełniania lub nawet konkretyzowania treści decyzji administracyjnych za pośrednictwem konsensualnych form działania organów administracji publicznej oraz podmiotów spoza systemu administracji publicznej. Są to rozwiązania wyjątkowe przede wszystkim dlatego, że zastosowanie niewładczej formy działania (najczęściej o charakterze kontraktualnym), uprzednio lub następczo warunkuje skuteczność prawną i wykonalność samej decyzji administracyjnej. Dochodzi zatem do odwrócenia określonego porządku zależności kompetencyjnej. Treść realizacji administracyjnoprawnej kompetencji jurysdykcyjnej zostaje powiązana z realizacją kompetencji do działania niewładczego lub nawet uzależniona od realizacji tej kompetencji.

W powyższym kontekście warto rozważyć dwa zasadnicze typy powiązań merytorycznych konkretyzacji norm materialnoprawnych w formach jurysdykcyjnej i konsensualnej.

Pierwszy typ powiązań bazuje na uzależnieniu skuteczności prawnej i wykonalności decyzji administracyjnej od następczego zawarcia umowy cywilnoprawnej, której treść zawiera elementy konkretyzujące obowiązki 
i uprawnienia poddane już konkretyzacji w treści decyzji. Tego rodzaju powiązanie znajduje zastosowanie przede wszystkim w dziedzinach podlegających funkcjonalnej prywatyzacji zadań publicznych ${ }^{19}$. Prywatyzacja funkcjonalna (zwana również „prywatyzacją wykonywania zadań publicznych”, „częściową prywatyzacją zadań publicznych” lub „outsourcingiem” ${ }^{20}$ odnosi się do zmiany sposobu wykonywania zadań publicznych: $\mathrm{z}$ bezpośredniego na pośredni. Zadania zachowują wprawdzie swój publicznoprawny charakter, jednakże państwo wycofuje się z bezpośredniego ich wykonywania. W miejsce działań lub czynności podmiotów publicznych wchodzą działania lub czynności podmiotów prywatnych, które przejmują faktyczną realizację zadań publicznych. Państwo wykonując zadania publiczne za pośrednictwem podmiotów prywatnych, pozostaje jednak nadal odpowiedzialne w sensie prawnym za ich ostateczną realizację. Przekazanie podmiotowi prywatnemu bezpośredniej realizacji zadania publicznego wiąże się zatem z koniecznością zachowania przez organy państwa kompetencji kontrolnych, nadzorczych i koordynacyjnych względem podmiotu wykonującego powierzone zadanie publiczne ${ }^{21}$.

Istotnym fragmentem instytucjonalnym $w$ zakresie prywatyzacji funkcjonalnej zadań publicznych są przepisy, które upoważniają podmioty prywatne z mocy samego prawa, na podstawie decyzji administracyjnej lub na mocy porozumienia z organami administracji publicznej do wykonywania określonych czynności (prawnych lub faktycznych) w ramach realizacji zadań publicznych ${ }^{22}$. Instytucje związane $\mathrm{z}$ powierzaniem podmiotom prywatnym wykonywania zadań lub funkcji publicznych są zbiorczo określane mianem „zlecania funkcji z zakresu administracji publicznej"23. Funkcje zlecone z zakresu administracji

${ }_{19}$ Na temat sposobu rozumienia pojęcia prywatyzacji zadań publicznych w literaturze polskiej zob. np. S. Biernat, Prywatyzacja zadań publicznych. Problematyka prawna, Warszawa 1994, s. 26-27; tenże, Die Privatisierung öffentlicher Aufgaben als Problem des Staats- und Verwaltungsrechts, w: Grundfragen des Verwaltungsrechts und der Privatisierung, Referate und Diskussionsbeiträge des VIII. Deutsch-Polnischen Verwaltungskolloquiums vom 7. bis 11. September 1992 in Krakau, red. S. Biernat, R. Hendler, F. Schoch, A. Wasilewski, Stuttgart - München - Hannover - Berlin Weimar - Dresden 1994, s. 187-188; L. Zacharko, Prywatyzacja zadań publicznych gminy. Studium administracyjnoprawne, Katowice 2000, s. 26 i n.; M. Kamiński, Die Varianten der Privatisierung öffentlicher Aufgaben in der polnischen Rechtsordnung und ihre verfassungsrechtlichen und gesetzlichen Grenzen, w: Instrumenten- und Akteursmix im Verwaltungsrecht, red. U. Kischel, H. Wißmann, Stuttgart - München - Hannover - Berlin - Weimar - Dresden 2014, S. 151 ff.

${ }_{20}$ Zob. np. M. Burgi, Funktionale Privatisierung und Verwaltungshilfe: StaatsaufgabendogmatikPhänomenologie-Verfassungsrecht, Tübingen 1999, s. 145 i n.

${ }^{21}$ M. Kamiński, Die Varianten der Privatisierung öffentlicher Aufgaben..., s. 151 i n.

${ }_{22}$ M. Kamiński, Formy partycypacji podmiotów prywatnych w procesach wykonywania zadań publicznych w polskim porządku prawnym", w: Zastosowanie idei public governance w prawie administracyjnym, red. I. Niżnik-Dobosz, Warszawa 2014, s. 86 i n.; tenże;

${ }_{23}$ Zob. np. M. Stahl, w: Prawo administracyjne. Pojęcia, instytucje, zasady w teorii i orzecznictwie, M. Stahl (red.), Z. Duniewska, B. Jaworska-Dębska, R. Michalska-Badziak, E. Olejniczak-Szałowska, Warszawa 2013, s. 293 i n. 
publicznej są wykonywane przez podmiot prywatny (niepubliczny) w imieniu państwa i na rachunek podmiotu zlecającego. Oznacza to, że podmioty prywatne partycypując $w$ procesie wykonywania zadań administracji publicznej nie przejmują zadań i kompetencji administracyjnych, lecz niejako w zastępstwie organów państwowych i pod ich nadzorem realizują pewne funkcje państwa z zakresu administracji publicznej tak władczej, jak i świadczącej.

Ustawowe podstawy kompetencyjne zlecania funkcji administracyjnoprawnych mogą bezpośrednio upoważniać podmioty prywatne do wykonywania zadań publicznych albo mogą wymagać konkretyzacji w drodze odpowiednich aktów lub porozumień z zakresu administracji publicznej. W przypadku konieczności wydania aktu konkretno-indywidualnego udzielającego upoważnienia do wykonywania funkcji administracyjnoprawnych zachodzi wyjątkowa sytuacja konkretyzacji ustawowej normy kompetencyjnej za pośrednictwem decyzji administracyjnej, która staje się bezpośrednią podstawą upoważnienia podmiotu prywatnego do podejmowania czynności administracyjnoprawnych w imieniu i na rachunek państwa. Decyzja administracyjna pełni zatem funkcję indywidualnego aktu kompetencyjnego, za pomocą którego podmiot zewnętrzny względem administracji publicznej uzyskuje upoważnienie lub także zostaje zobowiązany do wykonywania określonych kompetencji przypisanych do właściwych organów administracji publicznej. Na tym tle powstaje jednak problem pełnej konkretyzacji uprawnień i obowiązków podmiotu objętego zleceniem funkcji administracyjnych. Wielostopniowość konkretyzacji uprawnień lub obowiązków podmiotu, któremu powierzono wykonywanie zadań lub funkcji administracyjnych, może rodzić określone problemy konstrukcyjne.

Powyższy problemy można dostrzec $\mathrm{w}$ treści regulacji wynikającej $\mathrm{z}$ art. 16 ustawy z dnia 29 stycznia 2004 r. o Inspekcji Weterynaryjnej ${ }^{24}$. Przepis art. 16 przewiduje, w ust. 1 pkt. 1 u.i.w., że jeżeli powiatowy lekarz weterynarii z przyczyn finansowych lub organizacyjnych nie jest w stanie wykonać ustawowych zadań Inspekcji, może on wyznaczać na czas określony lekarzy weterynarii niebędących pracownikami Inspekcji do wykonywania określonych czynności weterynaryjnych (np. w zakresie szczepień ochronnych lub badań rozpoznawczych, sprawowania nadzoru nad miejscami gromadzenia, skupu lub sprzedaży zwierząt, targowiskami oraz wystawami, pokazami lub konkursami zwierząt, badania zwierząt umieszczanych na rynku, przeznaczonych do wywozu oraz wystawiania świadectw zdrowia, sprawowania nadzoru nad ubojem zwierząt rzeźnych, $w$ tym badania przedubojowego i poubojowego, oceny mięsa i nadzoru nad przestrzeganiem przepisów o ochronie zwierząt $w$ trakcie uboju, badania mięsa zwierząt łownych). Jednocześnie w art. 16 ust. 2 u.i.w. przewidziano, że wyznaczenie do wykonania powyższych czynności następuje w drodze decyzji

${ }^{24}$ Dz. U. z 2018 r. poz. 36 ze zm. Ustawa zwana dalej „u.i.w.”. 
administracyjnej powiatowego lekarza weterynarii, określającej rodzaj i zakres czynności przekazanych do wykonania. Konkretyzacja normy kompetencyjnej wynikającej $\mathrm{z}$ art. 16 ust. $2 \mathrm{w}$ zw. $\mathrm{z}$ art. 16 ust. 1 u.i.w. nie jest jednak zupełna, ponieważ zgodnie $\mathrm{z}$ art. 16 ust. 3 u.i.w. określenie zakresu, terminów i miejsca wykonywania czynności weterynaryjnych przez upoważnionego lekarza weterynarii oraz wysokości i terminów płatności przysługującego mu wynagrodzenia następuje w cywilnoprawnej umowie zawieranej pomiędzy powiatowym lekarzem weterynarii a upoważnionym lekarzem.

Jakkolwiek wielostopniowa (etapowa) oraz mieszana (decyzyjno-umowna) konkretyzacja normy kompetencyjnej może budzić pewne wątpliwości konstrukcyjne, to jednak w orzecznictwie Naczelnego Sądu Administracyjnego uznaje się, że „zastosowanie obok decyzji administracyjnej także umowy jako formy prawnej zlecania funkcji administracyjnych jest dopuszczalnym konstytucyjnie zabiegiem ustawodawczym"25. Umowa zawierana na podstawie art. 16 ust. 3 u.i.w. ma niewątpliwie na celu konkretyzację decyzji upoważniającej do wykonywania funkcji administracyjnych oraz jej wykonanie. Można nawet twierdzić, że umowa ta ma z jednej strony charakter wykonawczy i zależny względem powyższej decyzji, $\mathrm{z}$ drugiej zaś - stanowi ona w niezbędnym zakresie konkretyzację określonych elementów treściowych samej decyzji. Jest ponadto rzeczą niewątpliwą, że zawarcie umowy tego rodzaju stanowi warunek uzyskania przez decyzję $z$ art. 16 ust. 2 u.i.w. przymiotu wykonalności, albowiem zgodnie $\mathrm{z}$ art. 16 ust. 3 u.i.w. wykonywanie czynności, o których mowa w art. 16 ust. 1 u.i.w., następuje po zawarciu umowy z powiatowym lekarzem weterynarii. Decyzja upoważniająca lekarza weterynarii do wykonywania czynności weterynaryjnych $w$ imieniu powiatowego lekarza weterynarii nie może być zatem wykonana bez uprzedniego zawarcia oraz wejścia w życie umowy określającej szczegółowy zakres ${ }^{26}$, terminy i miejsce wykonywania czynności oraz wyso-

${ }^{25}$ Zob. wyrok NSA z dnia 24 kwietnia 2018 r., sygn. akt II OSK 2324/17, niepublik.

${ }^{26}$ Por. wyrok NSA z dnia 24 kwietnia 2018 r., sygn. akt II OSK 2324/17: „Z woli ustawodawcy szczegółowy zakres przedmiotowy tych czynności, terminy i miejsce ich wykonywania oraz warunki wynagradzania za wykonane czynności ma określać umowa cywilnoprawna zawierana przez organ Inspekcji Weterynaryjnej z wyznaczonym lekarzem weterynarii. Oznacza to, że w treści samej decyzji wystarczy określić kategorie rodzajowe czynności weterynaryjnych oraz zakres przedmiotowy tych czynności, natomiast dookreślenie zakresu przedmiotowego tych czynności oraz zakres czasowy i przestrzenny ich wykonywania oraz warunki wynagradzania za wykonane czynności mają zostać określone w umowie z art. 16 ust. 3 u.i.w. Jeżeli chodzi o rodzaje czynności weterynaryjnych, które mają zostać określone w decyzji, to w tym zakresie organ jest zobowiązany do wyboru odpowiednich kategorii czynności z katalogu ustawowego zawartego w art. 16 ust. 1 pkt. 1 i la u.i.w. Jeżeli natomiast chodzi o zakres przedmiotowy w ramach wybranych rodzajów czynności, to w tym zakresie w przedmiotowej sprawie należało kierować się katalogiem czynności szczegółowo określonych w załączniku do rozporządzenia" (obecnie rozporządzenia Ministra Rolnictwa i Rozwoju Wsi z dnia 15 stycznia 2018 r. w sprawie warunków i wysokości wynagrodzenia za wykonywanie czynności przez lekarzy weterynarii i inne osoby wyznaczone przez powiatowego lekarza weterynarii). 
kość i termin płatności wynagrodzenia za wykonane czynności. W tym sensie skonkretyzowane i zindywidualizowane upoważnienie wynikające $\mathrm{z}$ decyzji wyznaczającej lekarza weterynarii do wykonywania czynności należących do zakresu działania Inspekcji Weterynaryjnej nie wiąże się bezpośrednio z nałożeniem określonych obowiązków lub przyznaniem określonych uprawnień podmiotowi prywatnemu. Również samo upoważnienie ma charakter ogólny i warunkowy, skoro rozpoczęcie jego realizacji jest uzależnione od zawarcia umowy konkretyzującej zakres, termin i miejsce wykonywania czynności weterynaryjnych. Dopiero zawarcie powyższej umowy nie tylko konkretyzuje zakres i warunki wykonywania upoważnienia, lecz dodatkowo je aktualizuje. Warto również zauważyć, że sama umowa jest także właściwym źródłem obowiązku wykonywania upoważnienia udzielonego $\mathrm{w}$ decyzji wydanej na podstawie art. 16 ust. 2 u.i.w. $Z$ umowy tej wynikają także uprawnienia do wynagrodzenia za czynności weterynaryjne wykonane $w$ ramach realizacji powierzonych zadań. Pozwala to uznać, że umowa zawierana na podstawie i w granicach art. 16 ust. 3 u.i.w. zawiera elementy administracyjnoprawne i cywilnoprawne, które mają na celu konkretyzację decyzji upoważniającej do wykonywania funkcji administracyjnych.

Drugi typ powiązań treściowych pomiędzy formami konsensualnymi i jurysdykcyjnymi ma charakter odwrotny do rozważanego wyżej. W tym wypadku kierunek warunkowania treściowego przebiega od formy konsensualnej do formy decyzyjnej. Forma konsensualna poprzedza decyzję administracyjną, stając się warunkiem pełnej konkretyzacji normy materialnoprawnej i stosunku administracyjnoprawnego. Warunkowanie treści decyzji przez określony typ formy prawnej opartej na porozumieniu lub uzgodnieniu z podmiotami administrowanymi może przyjąć postać obligatoryjną albo alternatywną.

Reprezentatywnym przykładem alternatywnego warunkowania treści decyzji przez formę konsensualną jest ugoda w sprawie terminów i sposobu wnoszenia opłat adiacenckich. Ugoda ta może zostać zawarta w związku z wykonaniem

\footnotetext{
„Właściwy organ Inspekcji Weterynaryjnej jest więc uprawniony do ograniczenia w decyzji rodzajów czynności z art. 16 ust. 1 pkt. 1 i la u.i.w. przez określenie, że w ramach danej kategorii rodzajowej czynności będą realizowane jedynie niektóre typy tych czynności (np. w ramach rodzaju czynności: „pobieranie próbek do badań” będą realizowane jedynie czynności pobierania próbek krwi ssaków lub wymazów ptaków do badań laboratoryjnych albo próbek do badania w kierunku przenośnych gąbczastych encefalopatii przeżuwaczy). Dalsza konkretyzacja decyzyjnie wyznaczonego rodzaju i zakresu przedmiotowego czynności weterynaryjnych jest natomiast możliwa i dopuszczalna w treści umowy zawieranej na podstawie art. 16 ust. 3 u.i.w. Może ona w szczególności polegać na ograniczeniu ilościowym zakresu przedmiotowego czynności przekazanych do wykonania (np. przez określenie, że ilość pobranych próbek krwi ssaków do badań laboratoryjnych nie może przekroczyć określonej granicy) lub na dalszej precyzacji zakresu przedmiotowego (np. przez określenie, że czynności pobierania próbek krwi ssaków mają zostać ograniczone jedynie do bydła i koniowatych)”.
} 
uchwały o scaleniu i podziale nieruchomości oraz wydzieleniem nowych działek gruntu.

Podstawą wydzielenia nowych działek jest uchwała rady gminy o scaleniu i podziale nieruchomości (art. 104 u.g.n.). Szczegółowe zasady i tryb podejmowania uchwał w sprawach scalania nieruchomości i ich ponownego podziału na działki gruntu określają przepisy art. 101-108 u.g.n. Przepisy te mają zastosowanie do nieruchomości położonych na obszarach przeznaczonych w planach miejscowych na cele inne niż rolne i leśne, natomiast nie stosuje ich do nieruchomości, które zostały objęte postępowaniem scaleniowym na podstawie ustawy o scalaniu i wymianie gruntów (art. 101 ust. 2 i 3 u.g.n.). Przystąpienie do procedury scalania i ponownego podziału scalonych działek jest pozostawione uznaniu właściwej rady gminy. O przystąpieniu do scalenia i podziału nieruchomości decyduje rada gminy w drodze uchwały, określając w niej granice zewnętrzne gruntów objętych scaleniem i podziałem. Scalenia i podziału nieruchomości można dokonać, jeżeli są one położone w granicach obszarów określonych w planie miejscowym albo gdy o scalenie i podział wystąpią właściciele lub użytkownicy wieczyści posiadający ponad 50\% powierzchni gruntów objętych scaleniem i podziałem z tym zastrzeżeniem, że zabudowane części nieruchomości mogą być także objęte uchwałą o scaleniu i podziale za zgodą ich właścicieli lub użytkowników wieczystych. Treść powyższej uchwały jest determinowana treścią miejscowego planu zagospodarowania przestrzennego, który określa szczegółowe warunki scalenia i podziału nieruchomości (art. 102 ust. 1-4 u.g.n.).

Zgodnie $\mathrm{z}$ art. 107 u.g.n. osoby, które otrzymały nowe nieruchomości wydzielone $\mathrm{w}$ wyniku scalenia i podziału, są zobowiązane do wniesienia na rzecz gminy opłat adiacenckich w wysokości do 50\% wzrostu wartości tych nieruchomości, w stosunku do wartości nieruchomości dotychczas posiadanych. Przy ustalaniu wartości dotychczas posiadanych nieruchomości nie uwzględnia się wartości urządzeń, drzew i krzewów, o których mowa w art. 106 ust. 1, jeżeli zostało za nie wypłacone odszkodowanie (ust. 1). Wysokość stawki procentowej opłaty adiacenckiej ustala rada gminy w uchwale o scaleniu i podziale nieruchomości (ust. 2). Terminy i sposób wnoszenia opłat adiacenckich ustala wójt, burmistrz albo prezydent miasta, $w$ drodze ugody z osobami zobowiązanymi do ich zapłaty, przez podpisanie protokołu uzgodnień. W razie niedojścia do ugody, o terminie i sposobie zapłaty rozstrzyga rada gminy, podejmując uchwałę o scaleniu i podziale nieruchomości. Termin ustalony w uchwale nie może być krótszy niż termin wybudowania urządzeń infrastruktury technicznej (ust. 3).

Powyższa ugoda w sprawie terminów i sposobu wnoszenia opłat adiacenckich albo - w razie niedojścia ugody do skutku - uchwała o scaleniu i podziale nieruchomości są następnie podstawą do wydania przez właściwy organ wykonawczy gminy (wójta, burmistrza albo prezydenta miasta) decyzji o ustaleniu wysokości opłaty adiacenckiej 
(zob. art. 107 ust. 4 u.g.n.). Bez uprzedniego określenia terminów oraz sposobu wnoszenia opłat wydanie decyzji ustalającej opłatę nie jest możliwe. Jakkolwiek więc właściwa rada gminy podejmując uchwałę o scaleniu i podziale nieruchomości rozstrzyga już o terminach i sposobie zapłaty opłat adiacenckich (art. 104 ust. 2 pkt 7 w Zw. $z$ art. 107 ust. 3 zd. 2 u.g.n.), to jednak zgodnie $\mathrm{z}$ art. 107 ust. $3 \mathrm{zd}$. 1 u.g.n. pierwszeństwo w zakresie ustalenia terminów i sposobu wnoszenia opłat ma ugoda zawarta przez organ wykonawczy gminy z osobami zobowiązanymi do zapłaty. Dopiero w razie niedojścia ugody do skutku terminy i sposób uiszczenia opłat są regulowane przez postanowienia uchwały scaleniowo-podziałowej. Można na tej podstawie stwierdzić, że ugoda w sprawie opłat adiacenckich jest alternatywną formą konsensualnego kształtowania stosunku administracyjnoprawnego, która ma pierwszeństwo przed władczą regulacją wynikającą z uchwały o scaleniu i podziale. Podjęcie próby ugodowego ustalenia terminów i sposobu wnoszenia opłat adiacenckich jest ponadto obowiązkiem właściwego wójta, burmistrza lub prezydenta miasta. W ten sposób ugoda w sprawie opłaty adiacenckiej jako konsensualna forma działań organu administracji może warunkować i kształtować treść przyszłej decyzji ustalającej tę opłatę.

\section{Bibliografia końcowa:}

Biernat S., Prywatyzacja zadań publicznych. Problematyka prawna, Warszawa 1994, s. 26-27

Biernat S., Die Privatisierung öffentlicher Aufgaben als Problem des Staats- und Verwaltungsrechts, w: Grundfragen des Verwaltungsrechts und der Privatisierung, Referate und Diskussionsbeiträge des VIII. Deutsch-Polnischen Verwaltungskolloquiums vom 7. bis 11. September 1992 in Krakau, red. S. Biernat, R. Hendler, F. Schoch, A. Wasilewski, Stuttgart - München - Hannover - Berlin - Weimar - Dresden 1994, s. 187-188

Boć J., Działalność konsensualna (dwustronna i wielostronna), w: System prawa administracyjnego. Prawne formy działania administracji. Tom 5, red. R. Hauser, Z. Niewiadomski, A. Wróbel, Warszawa 2013, s. 234 i n.

Burgi M., Funktionale Privatisierung und Verwaltungshilfe: Staatsaufgabendogmatik-PhänomenologieVerfassungsrecht, Tübingen 1999, s. 145 i n.

Kamiński M., Materialnoprawne wygaśnięcie i proceduralne stwierdzenie wygaśnięcia mocy obowiqzującej decyzji administracyjnej, w: Kodyfikacja postępowania administracyjnego. Na 50-lecie K.P.A., red. J. Niczyporuk, Lublin 2010, s. 255-264

Kamiński M., Die Varianten der Privatisierung öffentlicher Aufgaben in der polnischen Rechtsordnung und ihre verfassungsrechtlichen und gesetzlichen Grenzen, w: Instrumenten- und Akteursmix im Verwaltungsrecht, red. U. Kischel, H. Wißmann, Stuttgart - München - Hannover - Berlin Weimar - Dresden 2014, S. $151 \mathrm{ff}$.

Kamiński M., Publicznoprawne obowiazki informacyjne w sferze norm publicznego prawa gospodarczego na tle ustawy o dostępie do informacji publicznej, w: Informacje gospodarcze. Studium prawne, red. A. Walaszek-Pyzioł, Warszawa 2018, s. 29 i n.

Kamiński M., Formy partycypacji podmiotów prywatnych w procesach wykonywania zadań publicznych w polskim porzadku prawnym", w: Zastosowanie idei public governance w prawie administracyjnym, red. I. Niżnik-Dobosz, Warszawa 2014, s. 86 i n. 
Stahl M., w: Prawo administracyjne. Pojęcia, instytucje, zasady w teorii i orzecznictwie, M. Stahl (red.), Z. Duniewska, B. Jaworska-Dębska, R. Michalska-Badziak, E. Olejniczak-Szałowska, Warszawa 2013, s. 293 i n.

Woś T., Wywłaszczanie nieruchomości i ich zwrot, Warszawa 2010, s. 159 i n.

Wyporska-Frankiewicz J., Publicznoprawne formy działania administracji o charakterze dwustronnym, Warszawa 2010, s. 62 i n., 70 i n., 135 i n., 226 i n.

L. Zacharko, Prywatyzacja zadań publicznych gminy. Studium administracyjnoprawne, Katowice 2000, s. 26 in.

\section{Streszczenie}

Opracowanie zostało poświęcone problematyce konsensualnych form działań organów administracji publicznej lub podmiotów prywatnych, które zastępują lub uzupełniają decyzje administracyjne. W pierwszej części rozważań analizie poddano konsensualne formy działań administracyjnoprawnych stanowiących alternatywne formy prawne załatwiania spraw administracyjnych. Alternatywność tego rodzaju form polega na możliwości wyboru formy prawnej załatwienia sprawy administracyjnej, pierwszeństwie użycia formy konsensualnej i subsydiarności decyzji administracyjnej albo możliwości zastąpienia (substytucji) już wydanej decyzji administracyjnej przez określony typ formy konsensualnej. W części drugiej analizy omówiono i poddano teoretycznej ocenie rozwiązania normatywne ustanawiające podstawy kompetencyjne do uzupełniania lub nawet konkretyzowania treści decyzji administracyjnych za pośrednictwem uprzednich lub następczych konsensualnych form działania organów administracji publicznej oraz podmiotów spoza systemu administracji publicznej.

Słowa kluczowe: prawne formy działania administracji publicznej; konsensualne formy działania w prawie administracyjnym; decyzja administracyjna; ugoda administracyjna; umowa cywilnoprawna w działaniach administracji publicznej.

\section{Consensual forms of administrative-legal actions replacing or supplementing administrative decisions}

\section{Summary}

The study has been devoted to the issues of consensual forms of administrative-legal actions replacing or supplementing administrative decisions. The first part of considerations deals with the consensual forms which are the alternative legal forms of disposing of the administrative matters. The alternativity of these forms lies in the choice of the legal form of administrative matter disposing, the priority of using the consensual form and the subsidiarity of the administrative decision or in the legal possibility of replacing (substitution) the already issued decision with the consensual form. The second part of the analysis was focused on the normative solutions establishing the competence bases for the complementing or even concretizing of the administrative decision content by means of the consensual forms of the administrative authorities and private entities actions.

Keywords: legal forms of public administration actions; consensual forms of actions in administrative law; administrative decision; administrative settlement; civil law agreement in public administration activities. 